\title{
НАТУРАЛЬНЫЙ КОНЦЕНТРИРОВАННЫЙ КРАСИТЕЛЬ, СОДЕРЖАЩИЙ КОМПЛЕКС АНТОЦИАНОВЫХ ПИГМЕНТОВ И ПЕКТИНОВЫХ ВЕЩЕСТВ
}

\author{
N.Yu. Chesnokova, Yu.V. Prikhodko, L.V. Levochkina, \\ A.A. Kuznetsova, M.E. Fadeeva
}

\section{NATURAL CONCENTRATED DYE CONTAINING ANTOCIAN PIGMENT COMPLEX AND PECTIN SUBSTANCES}

\begin{abstract}
Чеснокова Н.Ю. - канд. биол. наук, доц. Департамента пищевых наук и технологий Школы биомедицины Дальневосточного федерального университета, г. Владивосток.

E-mail: chesn_natali@mail.ru
\end{abstract}

Приходько Ю.В. - д-р техн. наук, проф., директор Департамента пищевых наук и технологий Школы биомедицины Дальневосточного федерального университета, г. Владивосток.

E-mail: yv_prikhodko@mail.ru

Левочкина Л.В. - канд. техн. наук, проф. Департамента пищевых наук и технологий Школы биомедицины Дальневосточного федерального университета, г. Владивосток.

E-mail: vovslev@yandex.ru

Кузнецова A.A. - канд. техн. наук, доц. Департамента пищевых наук и технологий Школы биомедицины Дальневосточного федерального университета, г. Владивосток.

E-mail: alku1965@mail.ru

Фадеева M.E. - студ. 4-го курса Школы биомедицины Дальневосточного федерального университета, г. Владивосток.

E-mail: chesn_natali@mail.ru

Изучено влияние температуры и ультразвука на интенсивность извлечения антоцианового пигмента и пектиновых веществ. Показано, что спектры, описывающие интенсивность извлечения антоцианового пигмента черной смородины, имеют два максимума поглощения при длинах волн 510 и 280 нм. Установлено соответствие максимумов поглощения антоцианового пигмента длине волны 510 нм и пектиновых веществ, ассоциированных с полифенолами, длине волны 280 нм. Показано, что наиболее полно экстрагирование антоцианового пигмента и пектиновых ве-
Chesnokova N.Yu. - Cand. Biol. Sci., Assoc. Prof., Department of Food Sciences and Technologies, School of Biomedicine, Far Eastern Federal University, Vladivostok.

E-mail: chesn_natali@mail.ru

Prikhodko Yu.V. - Dr. Techn. Sci., Prof., Director, Department of Food Sciences and Technologies, School of Biomedicine, Far Eastern Federal University, Vladivostok.

E-mail: yv_prikhodko@mail.ru

Levochkina L.V. - Cand. Techn. Sci., Prof., Department of Food Sciences and Technologies, School of Biomedicine, Far Eastern Federal University, Vladivostok.

E-mail: vovslev@yandex.ru

Kuznetsova A.A. - Cand. Tech. Sci., Assoc. Prof., Department of Food Sciences and Technologies, School of Biomedicine, Far Eastern Federal University, Vladivostok.

E-mail: alku1965@mail.ru

Fadeeva M.E. - 4-Year Student, School of Biomedicine, Far Eastern Federal University, Vladivostok. E-mail: chesn_natali@mail.ru

ществ происходит при температуре $65^{\circ} \mathrm{C}$ в течение 30 мин. Увеличение температуры экстрагирования до $90{ }^{\circ} \mathrm{C}$ приводит к снижению интенсивности извлечения биологически активных веществ. Использование ультразвука по-разному влияет на интенсивность извлечения антоцианового пигмента и пектина, выделенных из ягодного сырья. Использование ультразвука для экстрагирования антоцианового пигмента увеличивает интенсивность его выделения. При ультразвуковой экстракции в течение 30 мин содержание антоцианового пигмента в растворе увеличивается на 
$50 \%$. Максимальное извлечение антоцианового пигмента наблюдается при ультразвуковой экстракции в течение 60 мин. Степень извлечения антоцианового пигмента повышается в 2,5 раза. Напротив, использование ультразвука для выделения пектиновых веществ приводит к уменьшению их количества в растворе. Полученный методом концентрирования краситель, содержащий антоциановый пигмент и пектиновые вещества, имеет темно-красный цвет и ярко выраженный запах черной смородины, густую сиропообразную консистенцию, содержит в своем составе 4,83 мг/мл антоцианового пигмента, обладает полной растворимостью.

Ключевые слова: черная смородина, антоциановый пигмент, пектин, ультразвуковая экстракция, концентрированный антоциановый краситель.

It was shown that the ranges describing the intensity of extraction of anthocyanin pigment of blackcurrant have two maxima of absorption with wave lengths of 510 and 280 nanometers. The compliance of maxima of absorption of anthocyanin pigment to the wavelength of 510 nanometers and pectinaceous substances associated with polyphenols, the wavelength of 280 nanometers was established. It is shown that is fullest extraction of anthocyanin pigment and pectinaceous substances occurred at the temperature of $65{ }^{\circ} \mathrm{C}$ within 30 minutes. The increase in temperature of extraction to $90{ }^{\circ} \mathrm{C}$ leads to the decrease in the intensity of extraction of biologically active agents. The use of ultrasound differently influences intensity of extraction of anthocyanin pigment and the pectin emitted from berry raw materials. The use of ultrasound for extraction of anthocyanin pigment increases the intensity of its allocation. At ultrasonic extraction within 30 minutes the maintenance of anthocyanin pigment in solution increases by $50 \%$. The maximum extraction of anthocyanin pigment was observed at ultrasonic extraction within 60 minutes. The extent of extraction of anthocyanin pigment raises by 2.5 times. On the contrary, the use of ultrasound for allocation of pectinaceous substances leads to the reduction of their quantity in solution. The dye received by concoction method containing anthocyanin pigment and pectinaceous substances has dark-red color and a pronounced smell of blackcurrant, thick syrupy consistency, contains in the structure $4,83 \mathrm{mg} / \mathrm{ml}$ anthocyanin pigment, possesses full solubility.

Keywords: blackcurrant, anthocyanin pigment, pectin, ultrasonic extraction, concentrated anthocyanin dye.

Введение. Тяжелая экологическая обстановка в результате загрязнения окружающей среды, использование антибиотиков в медицине и животноводстве, синтетических добавок в пищевом производстве, как правило, ведут к накоплению в организме свободных радикалов и канцерогенных веществ. Избыточное их накопление является причиной патологических процессов в человеческом организме, вызывающих преждевременное старение и развитие многих болезней. Вредное воздействие свободных радикалов и канцерогенов можно уменьшить систематическим употреблением пищевых продуктов, содержащих ингредиенты, обладающие высокой антирадикальной активностью либо способные связывать и выводить вредные вещества из организма. Примерами таких соединений могут служить пищевые волокна и полифенольные соединения, содержащиеся в растительных объектах.

Пектиновые вещества относятся к группе пищевых волокон, присутствующих во всех высших растениях, особенно во фруктах и ягодном сырье. Пектиновые вещества снижают уровень холестерина в крови, выводят из организма тяжелые металлы, радионуклиды, снижают токсичность антибиотиков, пролонгируют действие лекарственных препаратов [1-3].

Антоциановые пигменты составляют основу полифенольного комплекса целого ряда ягод, фрруктов, цветов и обладают высокой антирадикальной активностью. Экстракты антоциановых пигментов способны снижать уровень холестерина, препятствовать образованию тромбов, повышать эластичность сосудов, ускорять заживление ран, благоприятно влиять на зрение, способствовать профилактике онкологических заболеваний [4-6]. Кроме того, концентраты экстрактов антоциановых пигментов обладают высокой красящей способностью и используются в пищевой промышленности в качестве натуральных ингредиентов для придания цвета и аромата продукту. 
Способы получения натуральных пищевых красителей различны и зависят от условий эстрагирования извлекаемого пигмента и сопутствующих соединений, а также технологии получения красителя. Поэтому вопрос создания и разработки технологии получения натуральных красителей, обладающих высокой красящей способностью, безвредностью для организма человека и содержащих биологически активные вещества, в настоящее время остается актуальным.

Цель исследования. Определение условий извлечения антоцианового пигмента и пектиновых веществ из ягод черной смородины и получение на их основе концентрированного антоцианового красителя.

Задачи исследования: установление условий извлечения антоцианового пигмента и пектиновых веществ из ягод черной смородины, получение на их основе концентрированного антоцианового красителя и определение показателей его качества.

Объекты и методы исследования. В качестве объекта для выделения антоцианового пигмента использовали доступное, широко культивируемое в России пищевое сырье - замороженные ягоды черной смородины (Ríbes nígrum).

Растворы антоцианового пигмента получали путем гомогенизации размороженного и измельченного ягодного сырья с водой в соотношении 1:5 при температурах 65 и $90^{\circ} \mathrm{C}$ в течение 30 мин, затем отфильтровывали.

Ультразвуковую экстракцию растворов проводили с использованием ультразвуковой ванны Sonorex RK100H (Bandelin, Германия) в течение 30, 60 и 90 мин при температуре $30{ }^{\circ} \mathrm{C}$. Обработка образцов проводилась при частоте воздействия 35 кГц и мощности 80 Вт.

Для выделения растворимого пектина измельченное ягодное сырье гомогенизировали с водой в соотношении 1:3. Для гидролиза протопектина в раствор добавляли $1 \mathrm{~cm}^{3}$ лимонной кислоты и экстрагировали при температуре $95^{\circ} \mathrm{C}$ в течение 90 мин. По окончании процесса проводили разделение твердой и жидкой фаз центрифугированием при 1000 об/мин в течение 5 мин. Растворимые пектиновые вещества выделяли путем осаждения их из жидкой фазы

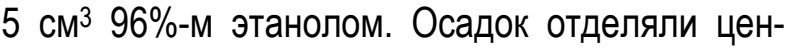

трифугированием при 1000 об/мин в течение 15 мин, водный раствор и осадок использовали для определения растворимых пектиновых веществ.

Съемку дифференциальных УФ-спектров образцов проводили на спектрофоотометре UV1800 Shimadzu (Япония) в интервале длин волн 200-800 HM.

Для получения концентрированного антоцианового красителя более плотную, вязкую фрракцию, полученную при выделении растворимых пектиновых веществ, концентрировали на вакуумном (роторном) испарителе Неі-VAP Advantage ML/G3B (Германия).

Растворимость концентрированного антоцианового красителя определяли при температуре $20-25^{\circ} \mathrm{C}$. К 300 мл воды добавляли 3 мл концентрированного натурального красителя, тщательно перемешивали и отмечали прозрачность раствора, наличие осадка и мути.

Содержание сухих веществ определяли рефррактометрическим методом по ГОСТ 590073. Кислотность (pH) красителя определяли при температуре $20^{\circ} \mathrm{C}$ по ГОСТ 27403-87.

Количественное содержание антоцианов в концентрированном антоциановом красителе определяли в соответствии с методикой, описанной в работе [7]. Образцы антоцианового пигмента разбавляли системой этанол/вода/соляная кислота (60/30/1) и измеряли их поглощение при длине волны 540 нм на спектрофотометре «SHIMADZU UV-1800» (Япония). Концентрацию антоцианов в растворах рассчитывали по формуле

$$
C=16,7 A_{540} d / 100 \text {, }
$$

где d - коэффицциент разбавления; А540нм - поглощение растворов при длине волны 540 нм; С - содержание антоцианов, мг/мл, выраженное как мальвидин-3-гликозид эквивалент.

Результаты исследования и их обсуждение. Поскольку условия выделения определяют экстрагирование биологически активных веществ из растительных объектов, в работе было исследовано влияние температуры на интенсивность извлечения антоцианового пигмента из ягод черной смородины. Зависимость интенсивности извлечения антоцианового пигмента от температуры представлена на рисунке 1. 


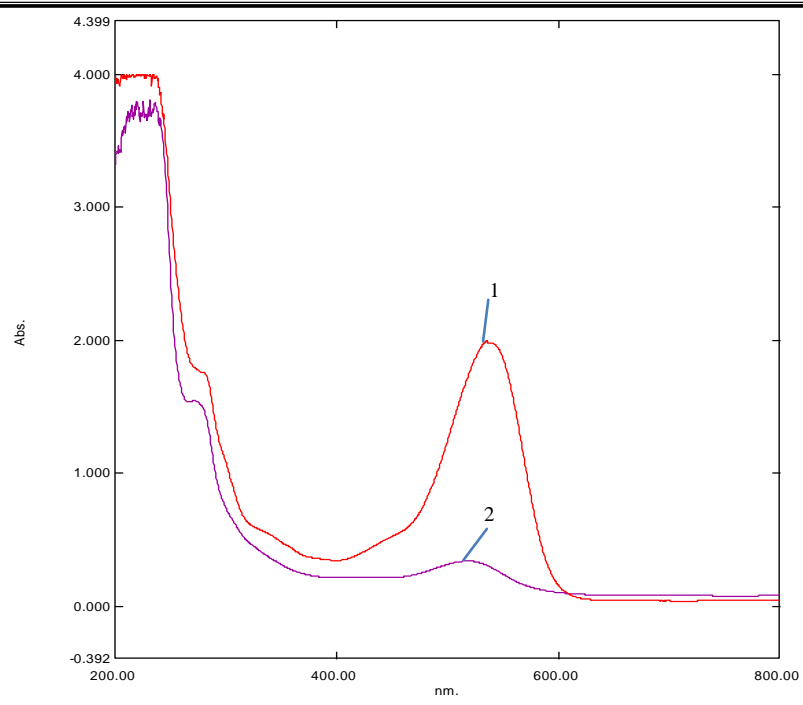

Puс. 1. Зависимость интенсивности извлечения антоцианового пигмента от температуры экстрагирования: $1-65^{\circ} \mathrm{C} ; 2-90^{\circ} \mathrm{C}$

Из полученных результатов видно, что спектры, описывающие интенсивность извлечения антоцианового пигмента черной смородины, имеют два максимума поглощения при длинах волн 510 и 280 нм. В предыдущих исследованиях [8] показано, что максимум поглощения антоцианового пигмента наблюдается при длине волны 510 нм.

Из рисунка 1 видно, что наиболее полно экстрагирование антоцианового пигмента происходит при температуре $65^{\circ} \mathrm{C}$ в течение 30 мин. Увеличение температуры экстрагирования до $90{ }^{\circ} \mathrm{C}$ приводит к снижению интенсивности извлечения пигмента, видимо, это объясняется частичным его разрушением при высоких тем- пературах и длительном времени экстрагирования. Поэтому в дальнейших исследованиях в качестве контрольного образца использовали раствор антоцианового пигмента, выделенный при температуре $65^{\circ} \mathrm{C}$ в течение 30 мин.

С целью выяснения компонента раствора антоцианового пигмента, проявляющего максимум поглощения при длине волны 280 нм, было проведено сравнение спектров водных растворов антоцианового пигмента черной смородины и яблочного пектина. Спектры поглощения антоцианового пигмента черной смородины и 1,5\%-го водного раствора пектина представлены на рисунке 2.

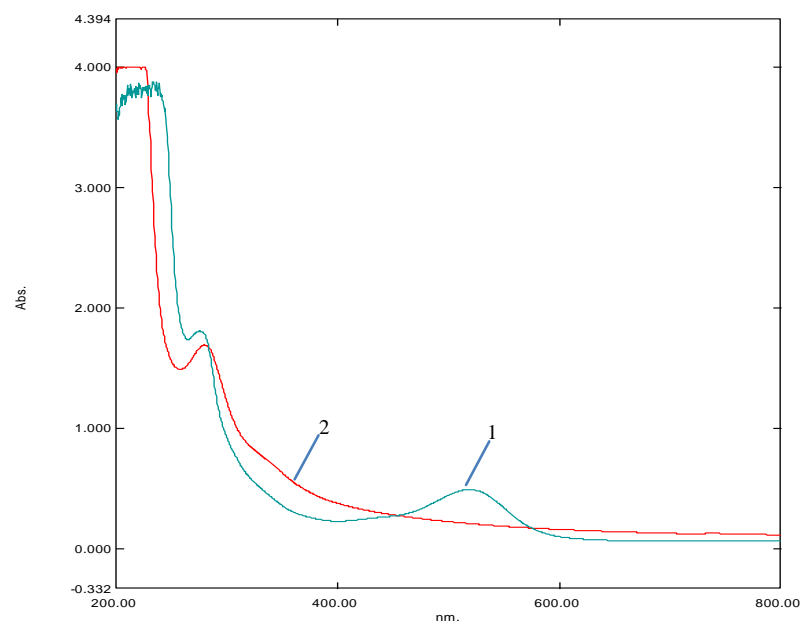

Puc. 2. Спектры поглощения антоцианового пигмента черной смородины (1) и 1,5\%-го водного раствора яблочного пектина (2) 
Из рисунка 2 видно, что растворы яблочного пектина и антоцианового пигмента имеют максимум поглощения при длине волны 280 нм. Это свидетельствует о том, что в растворе антоцианового пигмента, выделенного из ягод черной смородины, содержатся пектиновые вещества, вероятно, как и другие полисахариды [9], прочно ассоциированные с полифенолами растительных клеток. Природа взаимодействия пока не изучена, но можно предположить, что в образовании комплекса принимают участие кислород простой эфирной связи полифенолов, двухва- лентные металлы и карбоксильные группы пектиновых веществ.

С целью интенсификации процесса экстрагирования было изучено влияние ультразвука на интенсивность извлечения антоцианового пигмента и растворимого пектина, выделенных из ягод черной смородины. Зависимость интенсивности извлечения антоцианового пигмента и растворимого пектина из ягод черной смородины от метода и времени выделения представлена на рисунке 3.

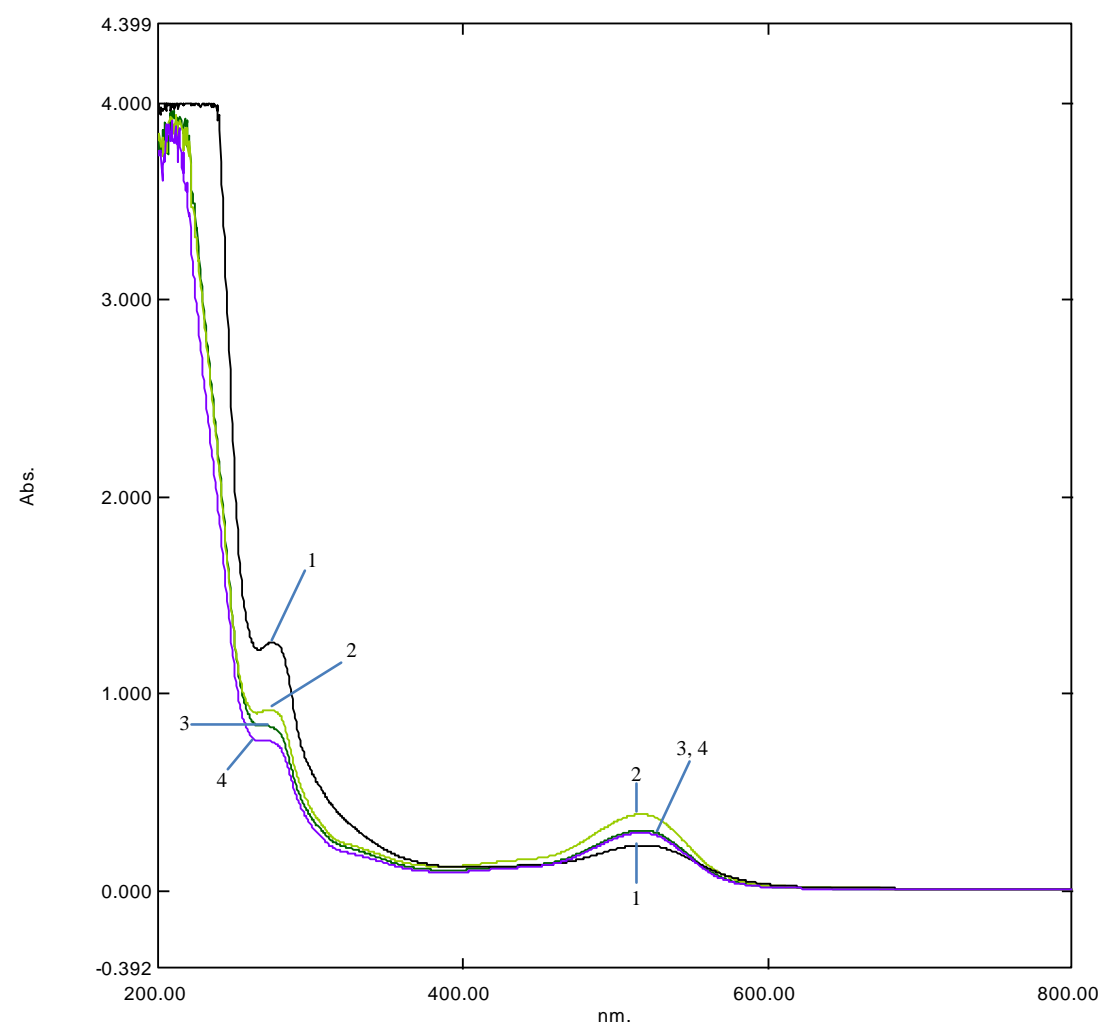

Pис. 3. Зависимость интенсивности извлечения антоцианового пигмента и растворимого пектина, выделенных из ягод черной смородины, от условий выделения: 1 - экстрагирование в течение 30 мин; 2 - ультразвуковая экстракция в течение 60 мин; 3 - ультразвуковая экстракция в течение 90 мин; 4 - ультразвуковая экстракция в течение 30 мин

Из рисунка 3 видно, что использование ультразвука по-разному влияет на интенсивность извлечения антоцианового пигмента и пектина, выделенных из ягодного сырья. Использование ультразвука для экстрагирования антоцианового пигмента увеличивает интенсивность его выделения. При ультразвуковой экстракции в течение 30 мин содержание антоцианового пигмента в растворе увеличивается на $50 \%$. Максимальное извлечение антоцианового пигмента наблюдается при ультразвуковой экстракции в течение 60 мин. Степень извлечения антоцианового пигмента повышается в 2,5 раза. Данные исследования согласуются с результатами работ [10], в которых также показано увеличение выхода антоцианового пигмента под действием ультразвуковых колебаний. Вероятно, это объясняется тем, что под действием ультразвуковых волн и кавитационного эфффекта, который они производят, происходит интенсификация 
массопередачи и более легкий доступ растворителя к растительной клетке. При этом распад кавитационных пузырей около стенок клеток приводит к разрушению клеточной стенки, способствуя более интенсивному проникновению внутрь клетки растворителя и тем самым более полному извлечению пигмента [11]. Более продолжительная ультразвуковая экстракция (90 мин) приводит к падению интенсивности извлечения антоцианового пигмента.

Напротив, использование ультразвука для выделения пектиновых веществ приводит к уменьшению их содержания в растворе. Вероятно, это связано с их деструкцией под действием ультразвуковых волн либо переходом растворимого пектина в нерастворимый протопектин.
Поскольку использование кислот способствует более полному гидролизу протопектина и переводу его в растворимый пектин [12] и, кроме того, увеличивает интенсивность извлечения антоцианового пигмента [13], в работе был проведен мягкий кислотный гидролиз пектиновых веществ черной смородины с использованием лимонной кислоты, последующим осаждением водного раствора этанолом и отделением более плотной вязкой фракции. Спектры поглощения раствора и осадка, полученных в процессе гидролиза пектиновых веществ лимонной кислотой с последующим осаждением этанолом, представлены на рисунке 4.

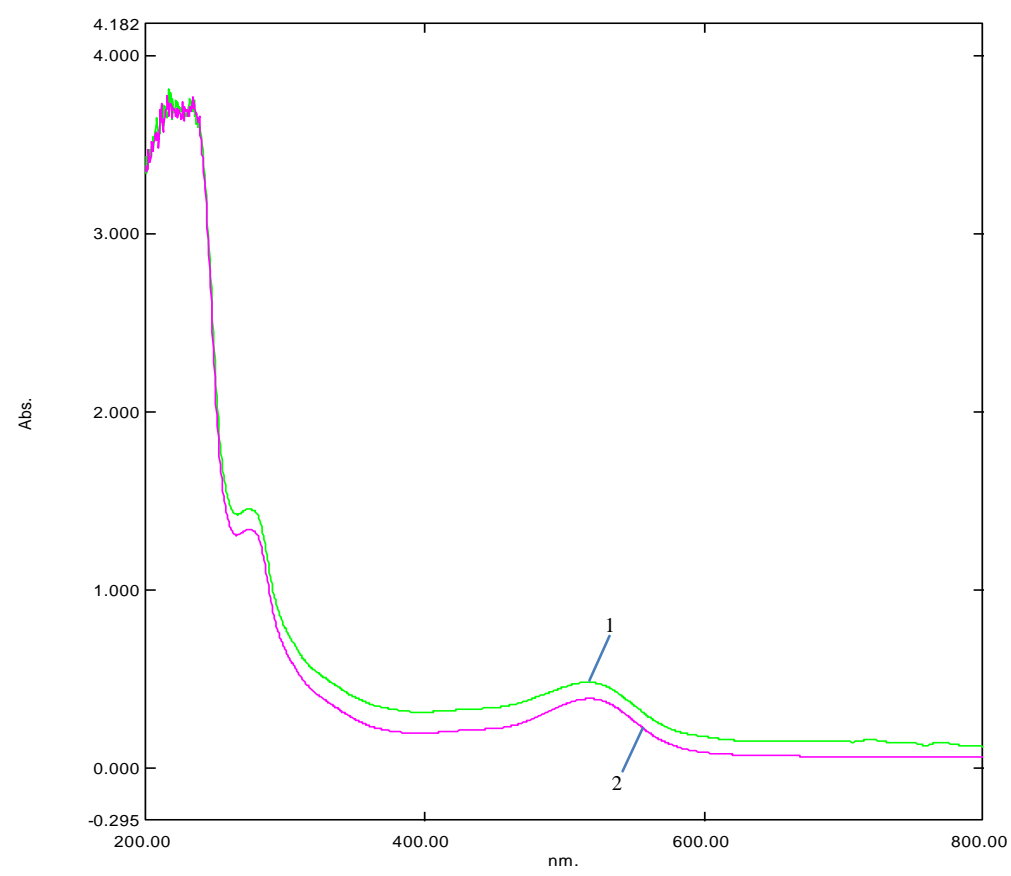

Puc. 4. Спектры поглощения раствора и осадка, полученных в процессе кислотного гидролиза пектиновых веществ: 1 - плотная, вязкая фракция; 2 - жидкая фрракция

Из представленных результатов видно, что как осадок, так и жидкая фрракция содержат растворимые пектиновые вещества и антоциановый пигмент. Наибольшее содержание пектиновых веществ и антоцианового пигмента обнаруживается в более плотном осадке. Содержание пектина и антоцианового пигмента в верхней жидкой фрракции меньше, их количество умень- шается в 1,4 и 1,2 раза соответственно. Поэтому в дальнейшем для получения концентрированного антоцианового красителя использовалась более плотная вязкая фракция.

Показатели качества антоцианового красителя из, черной смородины, полученного методом концентрирования, представлены в таблице. 
Вестник КрасТАУ. 2019. № 12

Показатели качества концентрированного антоцианового красителя из черной смородины

\begin{tabular}{|l|c|}
\hline \multicolumn{1}{|c|}{ Показатель } & Значение \\
\hline Внешний вид и цвет & $\begin{array}{c}\text { Густая сиропообразная жидкость } \\
\text { темно-красного цвета }\end{array}$ \\
\hline Запах & Яркий, выраженный запах черной смородины \\
\hline Массовая доля сухих веществ, \% & $18,2 \pm 0,05$ \\
\hline Содержание антоцианового пигмента, мг/мл & $4,83 \pm 0,01$ \\
\hline Растворимость в воде & Полная \\
\hline Кислотность (рН) & 1,8 \\
\hline
\end{tabular}

Из таблицы видно, что полученный методом концентрирования антоциановый краситель имеет темно-красный цвет и ярко выраженный запах черной смородины. Концентрированный антоциановый краситель имеет густую сиропо- образную консистенцию, содержит в своем составе 4,83 мг/мл антоцианового пигмента и обладает полной растворимостью.

Спектр поглощения концентрированного антоцианового красителя представлен на рисунке 5.

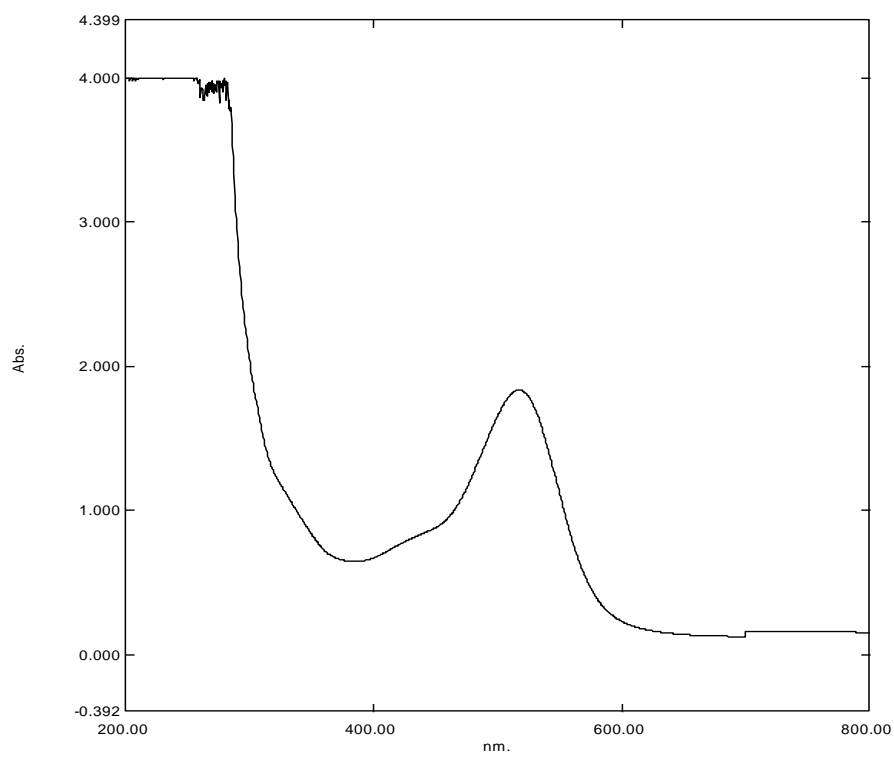

Puс. 5. Спектр поглощения концентрированного антоцианового красителя

Из представленных результатов видно, что в составе концентрированного антоцианового красителя наблюдается высокое содержание пектиновых веществ и антоцианового пигмента. Представленные данные позволяют предложить использовать концентрированный антоциановый краситель в качестве натурального красителя, содержащего биологически активные вещества, для окрашивания пищевых продуктов.

Выводы. Таким образом, определены режимы выделения антоцианового пигмента и пектиновых веществ из ягод черной смородины. Наиболее полное их экстрагирование происходит при температуре $65^{\circ} \mathrm{C}$ в течение 30 мин.
Использование ультразвуковой экстракции поразному влияет на интенсивность извлечения антоцианового пигмента и пектина, выделенных из ягодного сырья. Применение ультразвука увеличивает интенсивность экстрагирования антоцианового пигмента и уменьшает извлечение пектиновых веществ. Исследованы фризикохимические свойства антоцианового красителя, полученного методом концентрирования. Показано, что концентрированный краситель, содержащий антоциановый пигмент и пектиновые вещества, имеет темно-красный цвет, ярко выраженный запах черной смородины и густую сиропообразную консистенцию. 


\section{Литература}

1. Типсина Н.Н., Присухина Н.В., Машанов А.И. [и др.]. Возможность использования пектинового экстракта в производстве хлеба // Вестник КрасГАУ. - 2018. - № 3. C. $168-171$.

2. Родионова Л.Я., Донченко Л.В., Соболь И.В. [и др.]. Биохимические особенности пектиновых веществ дикорастущего растительного сырья // Тр. Кубан. гос. аграр. ун-та. 2015. - № 53. - С. 241-248.

3. Родионова Л.Я., Соболь И.В., Степовой А.В. Научные основы конструирования функциональных пектиносодержащих сухих продуктов целевого назначения // Новые технологии. - 2010. - № 2. - С. 73-77.

4. Mineo S., Noguchi A., Nagakura Y. [et al.]. Boysenberry polyphenols suppressed elevation of plasma triglyceride levels in rats // J. of Nutritional Science and Vitaminology. 2015. - 61(4). - P. 306-312.

5. Sorrenti V., Vanella L., Acquaviva R. [et al.]. Cyanidin induces apoptosis and differentiation in prostate cancer cells. International // J. of Oncology. - 2015. - 47(4). - P. 1303-1210.

6. Mazewski C., Liang K., Gozalez de Mejia E. Inhibitory potential of anthocyanin-rich purple and red corn extracts on human colorectal cancer cell proliferation in vitro // J. of Functional Foods. - 2017. - 34. - P. 254-265.

7. Ivanova V., Dornyei A., Mark $L$. [et al.]. Polyphenolic content of Vranec wines produced by different vinification conditions // Food Chemistry. - 2011. - 124. - P. 316-325.

8. Влияние желатина на степень выделения антоцианового пигмента жимолости и черной смородины / Н.Ю. Чеснокова, Л.В. Левочкина, Ю.В. Приходько [и др.] // Техника и технология пищевых производств. - 2017. № 4(47). - С. 92-97.

9. Выделение очищенного фукоидана из природного комплекса с полифренолами и его характеристика / А.М. Урванцева, И.Ю. Бакунина, Н.Ю. Ким [и др.] // Химия растительного сырья. - 2004. - № 3. - С. 15-24.

10. Чеснокова Н.Ю., Приходько Ю.В., Кузнецова А.А. Оценка влияния ультразвука на степень извлечения антоцианового пигмента черной смородины: мат-лы III Bсерос. науч.-практ. конф. / Приморская ГСХА. Уссурийск, 2018. - С. 183-189.

11. Bonfigli M., Godoy E., Reinheimer M.A. [et al.]. Comparison between conventional and ultrasound-assisted techniques for extraction of anthocyanins from grape pomace. Experimental results and mathematical modeling // Journal of Food Engineering. - 2017. № 207. - P. 56-72.

12. Михеева Л.А., Тры А.В. Выделение пектина из растительного сырья и изучение его некоторых химических свойств // Вестник ВГУ. Серия: Химия, биология, фармация. 2013. - № 2. - C. 53-56.

13. Patras A., Brunton N., O'Donnell C. [et al.]. Effect of thermal processing on anthocyanin stability in foods; mechanisms and kinetics of degradation // Trends in food science and technology. - 2010. - № 21. - P. 3-11.

\section{Literatura}

1. Tipsina N.N., Prisuhina N.V., Mashanov A.I. [i $d r$. . Vozmozhnost' ispol'zovanija pektinovogo jekstrakta v proizvodstve hleba // Vestnik KrasGAU. - 2018. - № 3. - S. 168-171.

2. Rodionova L.Ja., Donchenko L.V., Sobol' I.V. [i dr.]. Biohimicheskie osobennosti pektinovyh veshhestv dikorastushhego rastitel'nogo syr'ja // Tr. Kuban. gos. agrar. un-ta. - 2015. № 53. - S. 241-248.

3. Rodionova L.Ja., Sobol' I.V., Stepovoj A.V. Nauchnye osnovy konstruirovanija funkcional'nyh pektinosoderzhashhih suhih produktov celevogo naznachenija // Novye tehnologii. 2010. - № 2. - S. 73-77.

4. Mineo S., Noguchi A., Nagakura Y. [et al.]. Boysenberry polyphenols suppressed elevation of plasma triglyceride levels in rats // J. of Nutritional Science and Vitaminology. 2015. - 61(4). - P. 306-312.

5. Sorrenti V., Vanella L., Acquaviva R. [et al.]. Cyanidin induces apoptosis and differentiation in prostate cancer cells. International // J. of Oncology. - 2015. - 47(4). - P. 1303-1210.

6. Mazewski C., Liang K., Gozalez de Mejia E. Inhibitory potential of anthocyanin-rich purple and red corn extracts on human colorectal cancer cell proliferation in vitro // J. of Functional Foods. - 2017. - 34. - P. 254-265. 
7. Ivanova V., Dornyei A., Mark L. [et al.]. Polyphenolic content of Vranec wines produced by different vinification conditions /I Food Chemistry. - 2011. - 124. - P. 316-325.

8. Vlijanie zhelatina na stepen' vydelenija antocianovogo pigmenta zhimolosti i chernoj smorodiny / N.Ju. Chesnokova, L.V. Levochkina, Ju.V. Prihod'ko [i dr.] // Tehnika i tehnologija pishhevyh proizvodstv. - 2017. - № 4(47). S. 92-97.

9. Vydelenie ochishhennogo fukoidana iz prirodnogo kompleksa s polifenolami i ego harakteristika / A.M. Urvanceva, I.Ju. Bakunina, N.Ju. Kim [i dr.] // Himija rastitel'nogo syr'ja. 2004. - № 3. - S. 15-24.

10. Chesnokova N.Ju., Prihod'ko Ju.V., Kuznecova A.A. Ocenka vlijanija ul'trazvuka na stepen' izvlechenija antocianovogo pigmenta chernoj smorodiny: mat-ly III Vseros. nauch.-prakt. konf. / Primorskaja GSHA. - Ussurijsk, 2018. S. 183-189.

11. Bonfigli M., Godoy E., Reinheimer M.A. [et al.]. Comparison between conventional and ultrasound-assisted techniques for extraction of anthocyanins from grape pomace. Experimental results and mathematical modeling /I Journal of Food Engineering. - 2017. № 207. - P. 56-72.

12. Miheeva L.A., Try A.V. Vydelenie pektina iz rastitel'nogo syr'ja i izuchenie ego nekotoryh himicheskih svojstv // Vestnik VGU. Serija: Himija, biologija, farmacija. - 2013. - № 2. S. 53-56.

13. Patras A., Brunton N., O'Donnell C. [et al.]. Effect of thermal processing on anthocyanin stability in foods; mechanisms and kinetics of degradation // Trends in food science and technology. - 2010. - № 21. - P. 3-11. 